\title{
ATP2B3 wt Allele
}

National Cancer Institute

\section{Source}

National Cancer Institute. ATP2B3 wt Allele. NCI Thesaurus. Code C113766.

Human ATP2B3 wild-type allele is located within Xq28 and is approximately $65 \mathrm{~kb}$ in length. This allele, which encodes plasma membrane calcium-transporting AT Pase 3 protein, is involved in both cation transport and ATP hydrolysis. Mutation of the gene is associated with spinocerebellar ataxia, X-linked type 1. 